\title{
PREVALENCE OF INFECTION WITH PLEUROGONIUS MALACLEMYS HUNTER, 1961 (TREMATODA: DIGENEA) IN TRITIA OBSOLETA (SAY, 1822) (GASTROPODA: CAENOGASTROPODA: NASSARIIDAE) IN RELATION TO ENVIRONMENT QUALITY
}

\author{
PENNY DEMETRIADES
}

\begin{abstract}
Marine Academy of Technology and Environmental Science, 195 Cedar Bridge Road, Stafford Township, NJ 08050 United States (e-mail: demetriadespenny@gmail.com)

ABSTRACT: Tritia obsoleta (Say) is a snail inhabiting estuarine mudflats and salt marshes along the Eastern Coast of the United States. It is the intermediate host of Pleurogonius malaclemys whose definitive host is the diamondback terrapin (Malaclemys terrapin terrapin). P. malaclemys forms dome-like cysts on the snail's operculum. The study was aimed at observing differences in the snail's physical parameters (shell height, thickness, and snail weight) under the effect of the environmental quality and the prevalence of $P$. malaclemys. Snails were collected, along with samples of water and bottom deposits, from two locations in Barnegat Bay, New Jersey. In the area with poorer quality of sediment and water, the prevalence of parasite's cysts was significantly higher, and the shells were thinner and lower. Histological analyses revealed the presence of metacercariae and tissue anomalies. Increasing prevalence of the parasite was correlated with deteriorating ecosystem health, leading to a combined detrimental effect on the host. This study is a model of the repercussions of deteriorating habitat quality on host-parasite relationships, and the health of the organisms in question.
\end{abstract}

KEY WORDS: mud snail; Pleurogonius malaclemys; Malaclemys terrapin terrapin; shell composition; shell height; shell thickness; histology; habitat quality; parasite

\section{INTRODUCTION}

Assessment of host species of parasites in their natural habitats is crucial to our understanding of ecosystems and ecological interactions (CURTIS 2009a). The Eastern mud snail Tritia obsoleta (Say, 1822) is the intermediate host of the endoparasite Pleurogonius malaclemys, and the diamondback terrapin (Malaclemys terrapin terrapin) is its definitive host; all three species live in estuarine mudflats and salt marshes on the Eastern Seaboard of the United States (CURTIS 2009a, COHEN 2011, CHODKOWSKI et al. 2016). Metacercariae are parasites of $T$. obsoleta, whereas adult stages are found in $M$. terrapin terrapin; subsequently the larvae leave the terrapin to complete the cycle and enter the mud snail (Fig. 1). Without either the intermediate host (mud snail) or the definitive host (terrapin) the parasite would probably perish (LAFFERTY 2009). Cercariae of $P$. malaclemys are found attached to substrata other than snail opercula and shells, but these substrata are also components of the terrapin's diet, so that the life cycle of the parasite can continue (CHODKOWSKI et al. 2016).

When the larva attaches itself to the snail operculum, it immediately becomes encysted (HUNTER 1967); the cysts are pearl-like, and distinguish $P$. malaclemys from the eight other trematode parasites that infect T. obsoleta (ALTMAN 2010, BURKE 2016). 


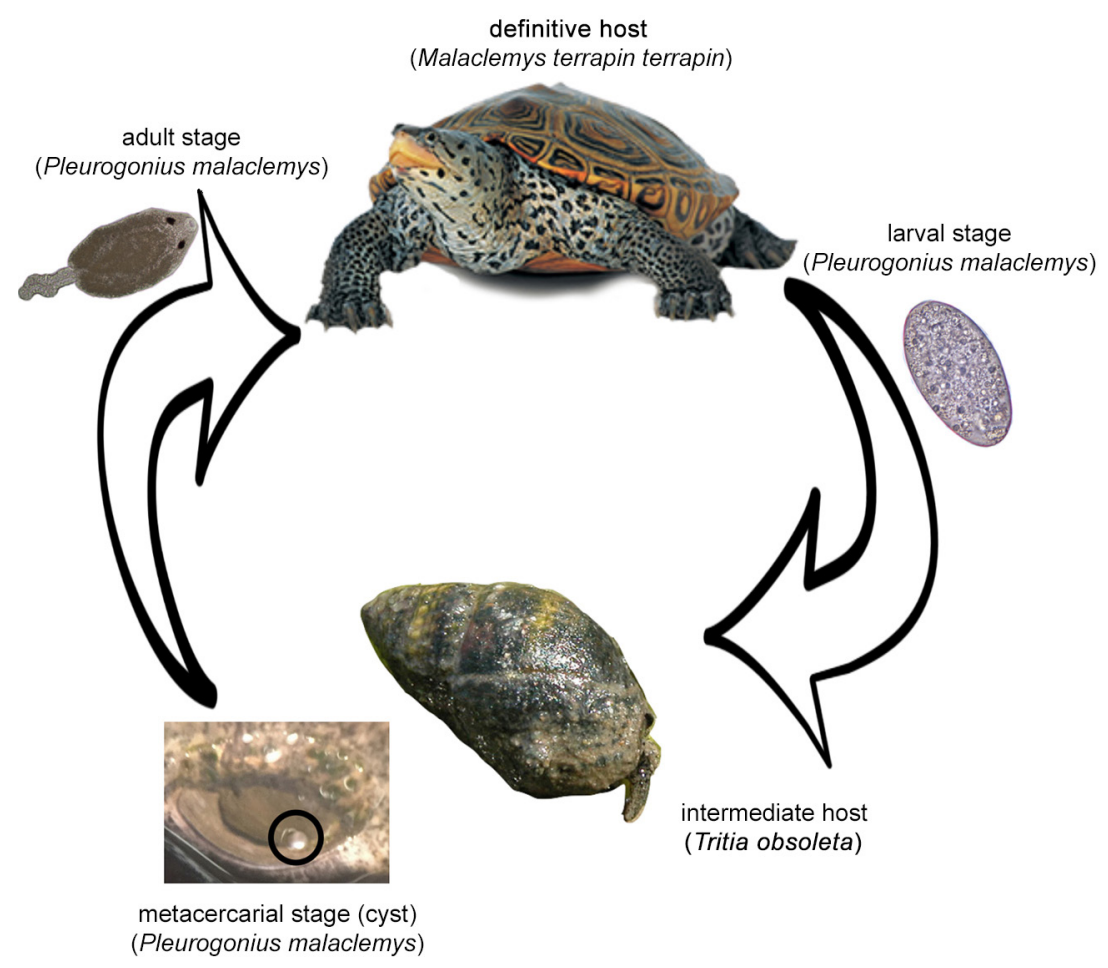

Fig. 1. Life cycle of Pleurogonius malaclemys

Prior studies indicate that the probability of snails acquiring parasitic infection is small (CURTIS 1997, 2009a). Parasites are known to infect weaker hosts, and higher infection rates were found to result from decreased environmental quality (SURES et al. 2017).

Barnegat Bay is not a conserved system, and is subject to anthropogenic influences which can greatly deteriorate the quality of natural habitats. The health of these ecosystems can be gauged through tests of the water column and substratum. Besides, nutrient-rich estuaries with rich algal growth and prominent epibiosis (here epibiosis refers to visible algae on snail shells) can be indicative of increased snail population (COHEN 2011, JOHNSON \& SHORT 2013).

\section{MATERIAL AND METHODS}

\section{SAMPLE COLLECTION}

Over the course of six months in 2018 (July through December), 14 samples of bottom deposits, water, and snail specimens were collected from each of two locations monthly. Water samples were collected in clean plastic containers above the area from which the snails were taken. Sediment samples were collected by removing the top five centimetres of the sediment from an area of 0.25 square metres. Approximately 150 snails were collected on each sampling date, to the total of 1,819 specimens.
Histological examination often reveals tissue changes which may reflect the deteriorating environmental quality. Shells, though for the most part composed of calcium carbonate $\left(\mathrm{CaCO}_{3}\right)$, may contain other compounds whose presence depends on the external conditions and the chemistry of the substratum (MIERZWA 2008).

The objective of this study was to examine the correlations between the prevalence of cysts of $P$. malaclemys, the differences in environmental quality, and the health and physical properties of Eastern mud snails, in order to gain a better insight into the effects of environmental parameters on marine organisms and the influence of parasites on their hosts.

\section{LOCATIONS}

Samples were collected from two different areas in Barnegat Bay, New Jersey: Island Beach State Park (IBSP) and the Long Beach Island Foundation conservation area (LBIF) (Fig. 2). LBIF (Figs 3-4) is 21 acres of marshland and has been conserved since 1997. IBSP (Figs 5-6) is designated as a state protected area; however, there is still a high degree of anthropogenic influence, as it is a popular tourist spot and people are allowed to boat and fish in the area. 


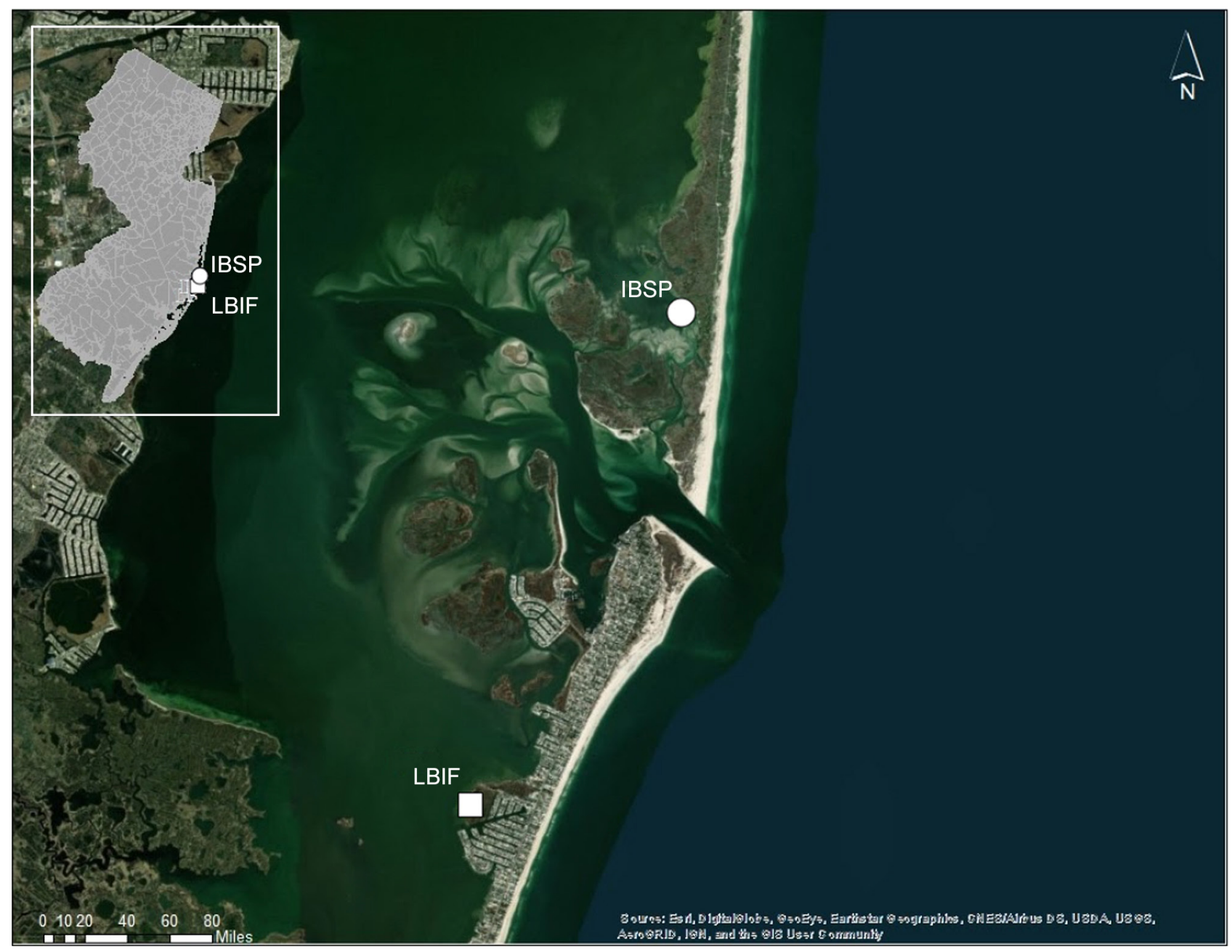

Fig. 2. Sampling localities: Island Beach State Park (IBSP) (circle) and Long Beach Island Foundation (LBIF) conservation area (square), New Jersey

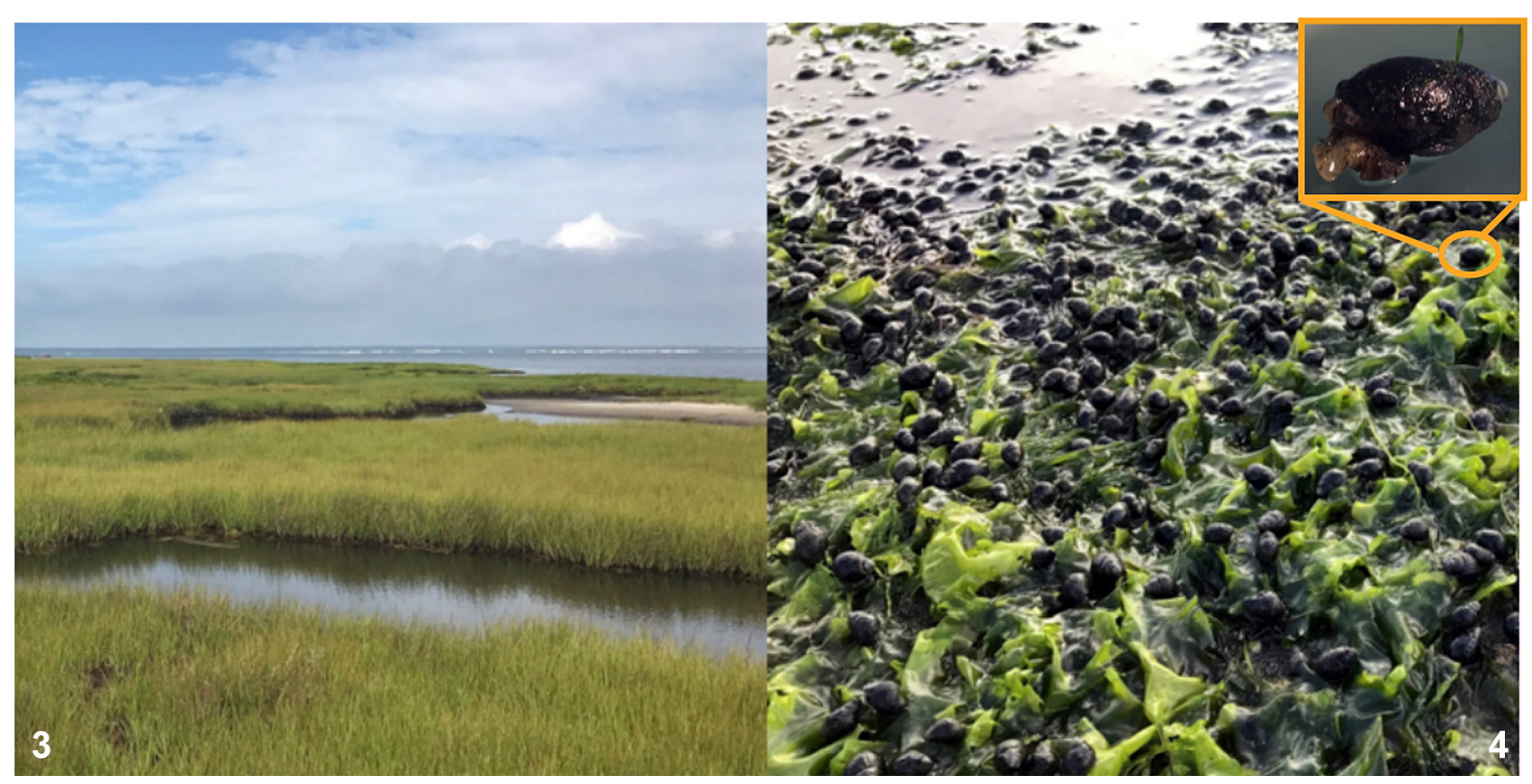

Figs 3-4. Long Beach Island Foundation conservation area (LBIF), New Jersey: 3 - landscape, 4 - mud snails (Tritia obsoleta) 


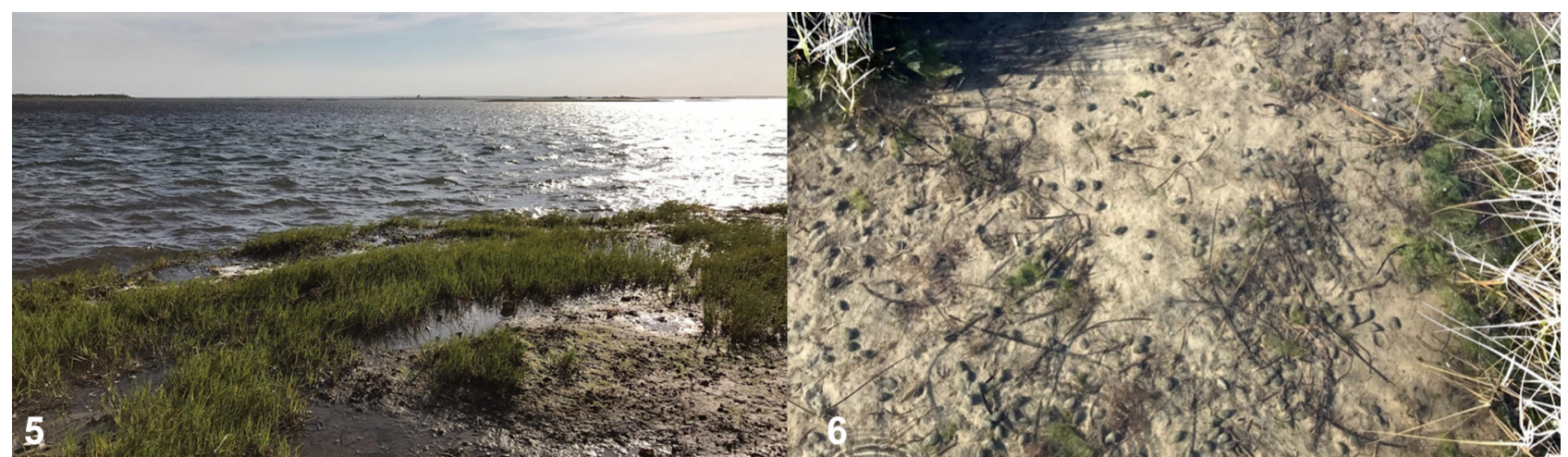

Figs 5-6. Island Beach State Park (IBSP), New Jersey: 5 - landscape, 6 - mud snails (Tritia obsoleta)
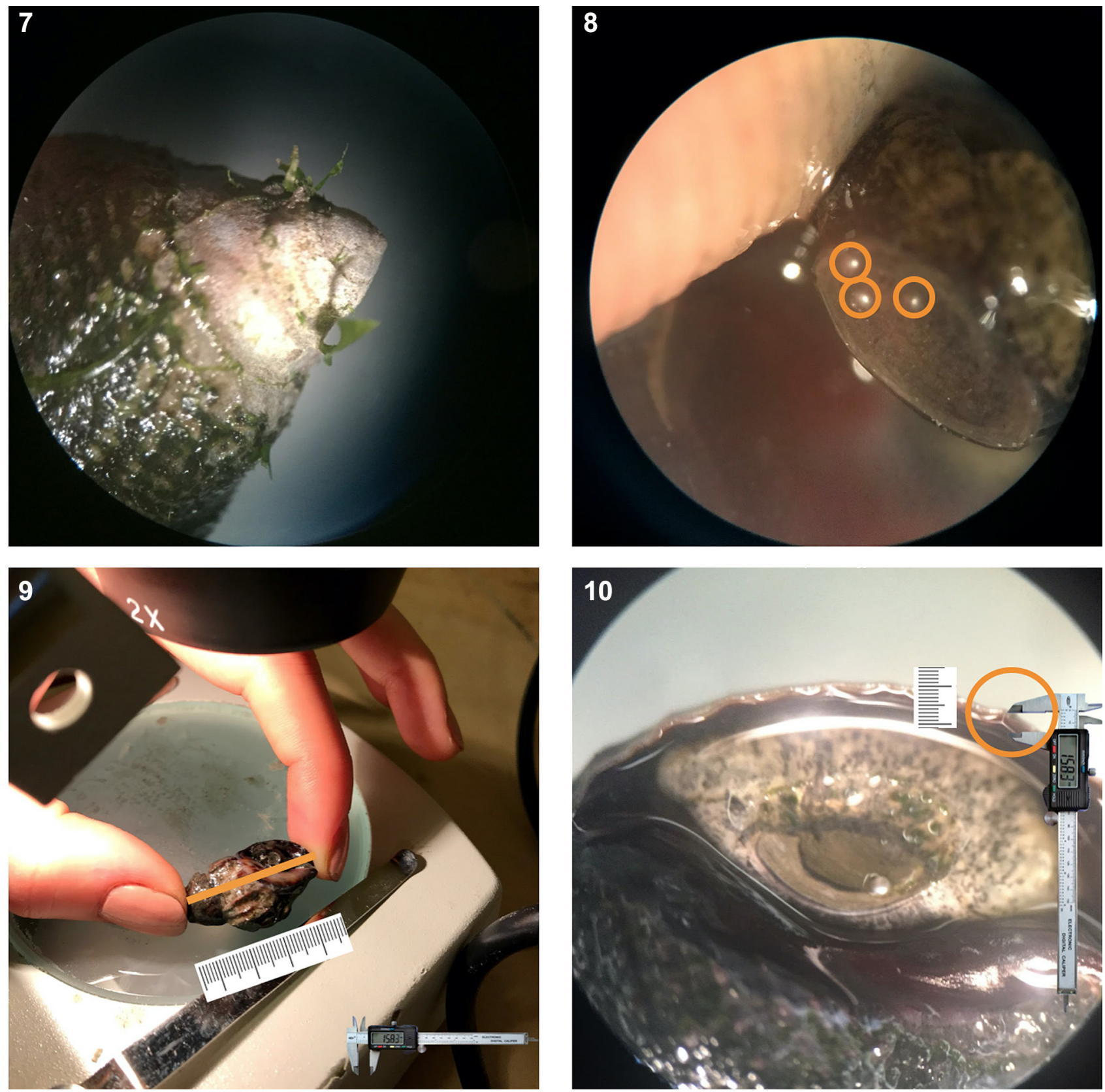

Figs 7-10. Physical parameters measured on each specimen of T. obsoleta: 7 - epibiosis on shell (visible under microscope or with naked eye), 8 - microscopic cysts of $P$. malaclemys on snail operculum (circled), 9 - shell height as measured with digital calliper (indicated with line), 10 - shell thickness as measured with digital calliper (indicated with circle) 


\section{PROCEDURES}

To determine water quality, three measurements of each of six parameters were taken in each sample: dissolved oxygen (ppm) with the Winkler Titration method, $\mathrm{pH}$ with an OHAUS pen $\mathrm{pH}$ meter $( \pm 0.1$ $\mathrm{pH})$, salinity (ppt) using a handheld refractometer $( \pm 0.1 \mathrm{ppt})$, turbidity (NTU) using an Aquafluor Handheld Turbidity Meter $( \pm 0.1$ NTU), and nitrates and phosphates with a portable LaMotte Colorimeter. Nitrates ( $\mathrm{ppm}$ ) were analysed using the zinc reduction method, and phosphates (ppm) were tested with the phosphate reduction method.

To determine sediment quality, three measurements were taken of each of three parameters in each sample: nitrates and phosphates with a portable LaMotte Colorimeter and organic matter content (\%) analysis using the ignition method with a Muffle Furnace at $450^{\circ} \mathrm{C}$ for 24 hours. Nitrates (ppm) were analysed with the zinc reduction method and phosphates (ppm) with the phosphate reduction method. Sediment samples were sent to the Cornell Nutrient Analysis Lab (CNAL) to determine total hydrogen, nitrogen, and carbon.

To assess the condition of snails, five parameters were recorded for each snail: presence of epibiosis (algae), number of cysts, shell height and thickness, and snail total weight (Figs 7-10). The shells were checked for the presence of cysts under a microscope, a carbon fibre digital calliper $( \pm 0.1 \mathrm{~mm})$ was used to measure the shell height $(\mathrm{mm})$ and thickness $(\mathrm{mm})$; the snails were individually weighed on a gram scale $( \pm 0.1 \mathrm{~g})$.

\section{RESULTS}

The water samples taken at LBIF had a significantly higher dissolved oxygen content and significantly lower nitrate, phosphate, $\mathrm{pH}$, salinity, and turbidity levels than those at IBSP (Table 1, p-values <0.05). The sediment samples at LBIF had significantly lower
Prior to histological examination, a sample of approximately 20 snails collected in February was classified in four categories: IBSP cyst, IBSP no cyst, LBIF cyst, and LBIF no cyst. The live snails were individually fixed in Bouin's solution for eleven days, and in $80 \%$ ethanol for two days (BIGHIU et al. 2017). The snail was then decalcified and the tissue was processed, embedded in paraffin (6-7 individuals per paraffin set), sectioned (one section $3 \mu \mathrm{m}$ thick per slide), and stained with haematoxylin and eosin at the Histowiz Laboratory, New York.

For chemical composition analysis, a sample of approximately 20 snails collected in March was classified in four groups: IBSP shells, IBSP no cyst, LBIF cyst, and LBIF no cyst. The snails were then removed from their shells and the shells were crushed. At the Stockton University Laboratory, New Jersey, a Bruker S1 Titan XRF spectrometer was used to determine the chemical composition of the shells.

\section{STATISTICAL ANALYSIS}

The shell height and thickness, snail weight, and cyst prevalence were compared between the two areas using T-Tests with Unequal Variance. The sediment and water quality parameters were compared between the two areas using T-Tests with Equal Variance, excluding CNAL results. The shell composition results were compared among the four groups with ANOVA and Tukey Post $\mathrm{Hoc}$, and were run with an $\mathrm{N}<30$. The shell height and thickness, and the snail weight were all tested for correlation with the cyst prevalence within each area by regression tests. An alpha value of 0.05 or less was used to determine significance.

Table 1. Mean and standard deviation of water quality parameters in IBSP and LBIF (T-Test, p <0.05)

\begin{tabular}{|c|c|c|c|c|c|c|}
\hline & $\begin{array}{c}\text { Dissolved } \\
\text { oxygen (ppm) }\end{array}$ & $\begin{array}{l}\text { Turbidity } \\
\text { (NTU) }\end{array}$ & $\begin{array}{c}\text { Phosphates } \\
\text { (ppm) }\end{array}$ & Nitrates (ppm) & $\mathrm{pH}$ & Salinity (ppt) \\
\hline \multicolumn{7}{|c|}{ IBSP } \\
\hline mean & 6.81 & 2.33 & 0.40 & 8.05 & 7.57 & 27.86 \\
\hline $\begin{array}{l}\text { standard } \\
\text { deviation }\end{array}$ & 1.09 & 3.51 & 0.41 & 8.41 & 0.42 & 1.96 \\
\hline \multicolumn{7}{|c|}{ LBIF } \\
\hline mean & 7.54 & 0.17 & 0.24 & 1.29 & 7.28 & 23.95 \\
\hline $\begin{array}{l}\text { standard } \\
\text { deviation }\end{array}$ & 1.30 & 0.15 & 0.14 & 1.62 & 0.38 & 2.09 \\
\hline \multicolumn{7}{|c|}{ T-test } \\
\hline p-values & 0.028 & 0.004 & 0.048 & 0.004 & 0.012 & $<0.0001$ \\
\hline
\end{tabular}


IBSP had a significantly greater prevalence of parasite's cysts $(12.1 \%)$, than LBIF $(2.9 \%)$ (p-value $<0.0001$ ). The shell height and thickness of LBIF snails were significantly greater than those of IBSP

Table 2. Mean and standard deviation of sediment quality parameters in IBSP and LBIF (T-Test, $\mathrm{p}<0.05)$

\begin{tabular}{lccc}
\hline & $\begin{array}{c}\text { Phosphates } \\
(\mathrm{ppm})\end{array}$ & $\begin{array}{c}\text { Nitrates } \\
(\mathrm{ppm})\end{array}$ & $\begin{array}{c}\text { Organics } \\
(\%)\end{array}$ \\
\hline \multicolumn{4}{c}{ IBSP } \\
\hline $\begin{array}{l}\text { mean } \\
\text { standard } \\
\text { deviation }\end{array}$ & 1.78 & 32.93 & 1.12 \\
\hline \multicolumn{5}{c}{0.62} & 24.16 & 1.04 \\
\hline $\begin{array}{l}\text { mean } \\
\text { standard } \\
\text { deviation }\end{array}$ & 0.55 & 3.60 & 21.45 \\
\hline \multicolumn{5}{c}{ LBIF } \\
\hline p-values & 0.39 & 5.25 & 15.84 \\
\hline
\end{tabular}

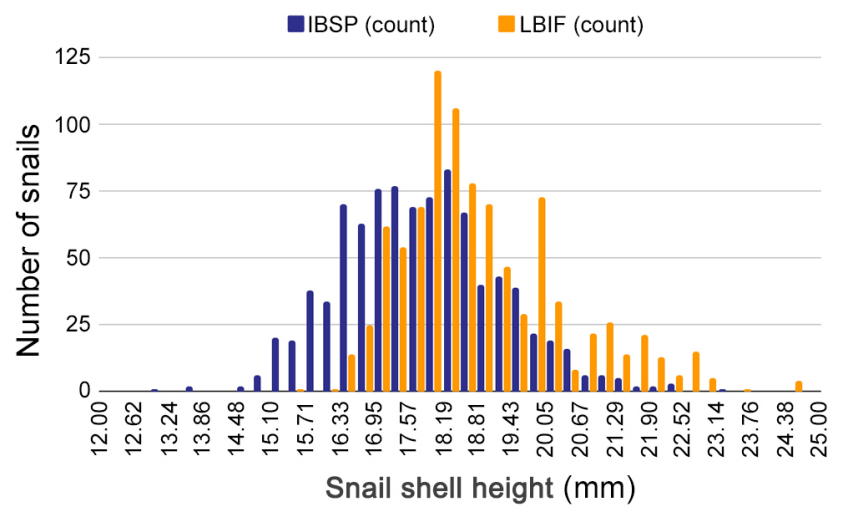

Fig. 11. Significant difference (T-Test, $\mathrm{t}=-15.4, \mathrm{p}<0.0001$ ) in shell height $(\mathrm{mm})$ between IBSP and LBIF $(\mathrm{N}-1,819)$

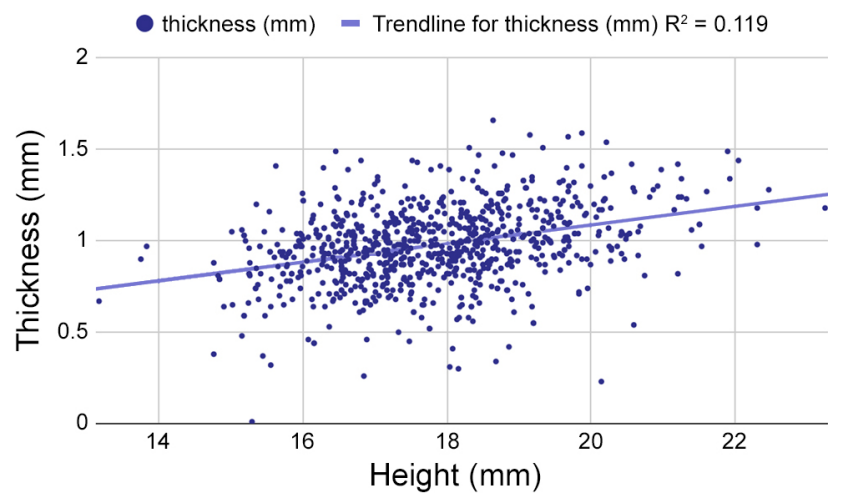

Fig. 13. Significant direct relationship (regression, p $<0.0001$, F-statistic $<0.0001$, correlation coefficient $0.345)$ between shell thickness and shell height at IBSP $(\mathrm{N}-903)$ snails (Figs 11 and 12, respectively). The shell thickness was correlated with shell height and the cyst prevalence was correlated with shell thickness in both areas (Figs 13 and 14, respectively). The proportion of epibiosis-carrying shells at LBIF and IBSP was $66.7 \%$ and $35.0 \%$, respectively.

Histological slides showed evidence of internal $P$. malaclemys trematodes, pathological lesions of tissue, and tissue anomalies in infected snails from both areas. The proportion of anomalies was the smallest in cyst-free snails from LBIF (Fig. 15).

No consistent differences in shell composition were found among the four samples (IBSP shells, IBSP no cyst, LBIF cyst, LBIF no cyst), except for a difference in strontium concentrations between cystfree LBIF snails and cyst-free IBSP snails. The mean calcium concentration was higher at LBIF (although not statistically significant). Arsenic, tantalum, tungsten, and gold were only found in IBSP shells.

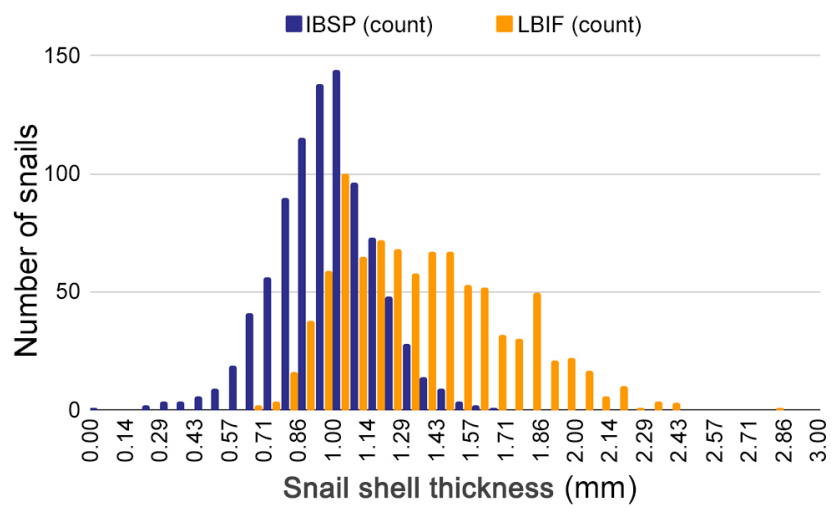

Fig. 12. Significant difference (T-Test, $\mathrm{t}=-29.4, \mathrm{p}<0.0001$ ) in shell thickness $(\mathrm{mm})$ between IBSP and LBIF $(\mathrm{N}-$ $1,819)$

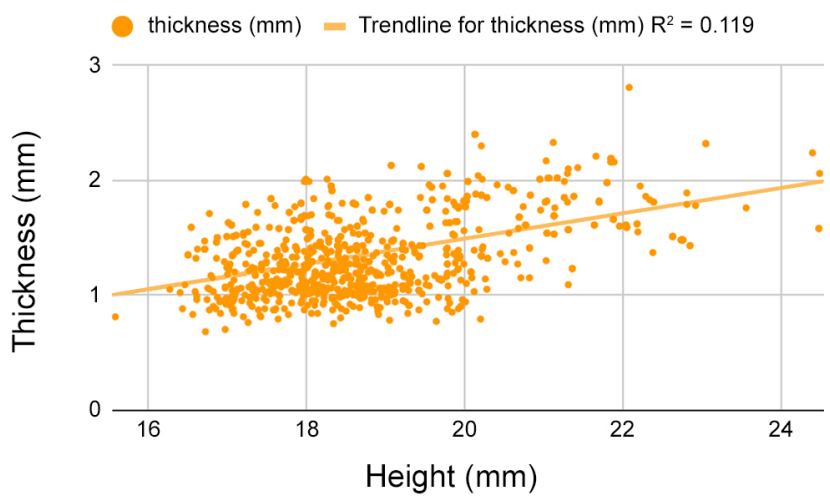

Fig. 14. Significant direct relationship (regression, p $<0.0001$, F-statistic $<0.0001$, correlation coefficient $0.48)$ between shell thickness and shell height at LBIF $(\mathrm{N}-916)$ 


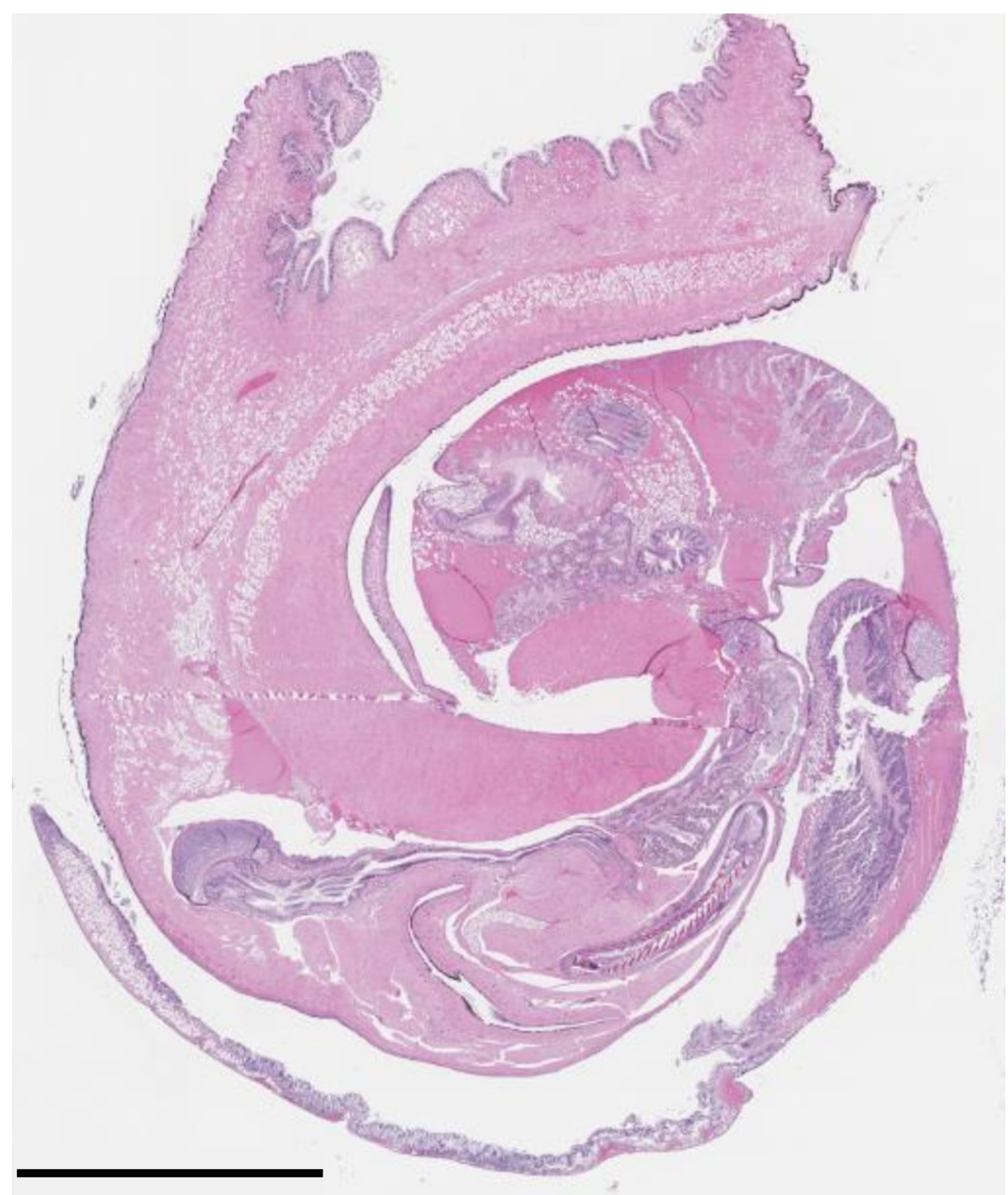

Fig. 15. Histological slide of cyst-free T. obsoleta from LBIF. No tissue lesions or anomalies were found. Scale bar $5 \mathrm{~mm}$

\section{DISCUSSION}

The significant differences in water quality parameters between the two areas indicate environmental differences, though the mean values for all three parameters were within the ranges which are typical of this system. The statistical significance of the differences in water parameters can be attributed to the areas' different location within the bay (IBSP north of Barnegat Inlet, LBIF south of the inlet) and the influence of varying currents, marine traffic, and natural bay processes. Still, the mean dissolved oxygen content at LBIF was slightly higher than at IBSP, which could indicate a water quality more favourable for aquatic life (BEJDA et al. 1992). The nitrate, phosphate, and turbidity levels measured within the water column were significantly higher at IBSP, indicating a poorer water quality; increased nitrate and phosphate levels are indicative of algal abundance and eutrophic conditions.
The significant differences in sediment quality (nitrates, phosphates, and organic matter) between the two areas indicate a difference in their habitat quality. Higher levels of nitrates and phosphates (IBSP) indicate increased runoff, non-point source pollution, and an accumulation of toxins within the sediment that is detrimental to marine organisms, including T. obsoleta (SONG et al. 2004). Organic matter in the soil is essential for health and productivity of benthic ecosystems and is a source of food for $T$. obsoleta; LBIF sediment has significantly higher organic matter content. Mud snail density is positively correlated with benthic microalgal biomass (organic matter) (JOHNSON \& SHORT 2013), indicating a higher density of snail populations at LBIF, which was also observed in this study. The higher total nitrogen, hydrogen, and carbon levels at LBIF indicate greater soil fertility, favouring more abundant plant 
growth and a higher content of organic matter. The combination of these factors indicates a better quality of mud snail habitat at LBIF.

The significant differences in shell height and thickness, and cyst prevalence between the two areas indicate a difference in the condition of the snails. The mean weight of LBIF snails was greater than that of IBSP snails. The cyst prevalence at LBIF was smaller, and the snails had higher and thicker shells than those found at IBSP. Though not correlated with shell height, the prevalence was correlated with shell thickness: cyst-bearing snails had thinner shells. While previous research (CURTIS 2009b) showed that the presence of cysts inhibited growth of T. obsoleta, in this study snails of all sizes were collected and no attempts were made to determine the growth rate pre- and post-infection, or the age. There are no literature data relating the susceptibility to infection to the snail's age. While the growth rate is affected by parasitic infection, the shell height is a function of age. The shell thickness is not solely dependent upon age, which allows the influence of the parasite to be revealed. Furthermore, in both areas shell thickness was correlated with shell height, indicating that any effect on the robustness of the shells due to the parasites is not conspicuous. The presence of the parasite produced significantly thinner shells, reducing crush resistance and making the snail vulnerable to further infection (GUSTAFSON \& BOLEK 2015). Additionally, the crush resistance of the shell of $T$. obsoleta serves as protection against the main predator, the diamondback terrapin (TUCKER et al. 1997). Any decrease in shell thickness, and consequently crush resistance, would increase the accessibility of the snail to the terrapin, further securing the continuation of the parasite's life cycle. Earlier studies showed that the prevalence of $P$. malaclemys in snails could serve as an indirect indicator of the abundance of $M$. terrapin terrapin (CHODKOWSKI et al. 2016). There is no observable difference in the terrapin population between the two areas, which could be expected due to the significantly higher prevalence of cysts on IBSP snails. Perhaps the cercariae are more prevalent on the opercula and within the tissue of the mud snails

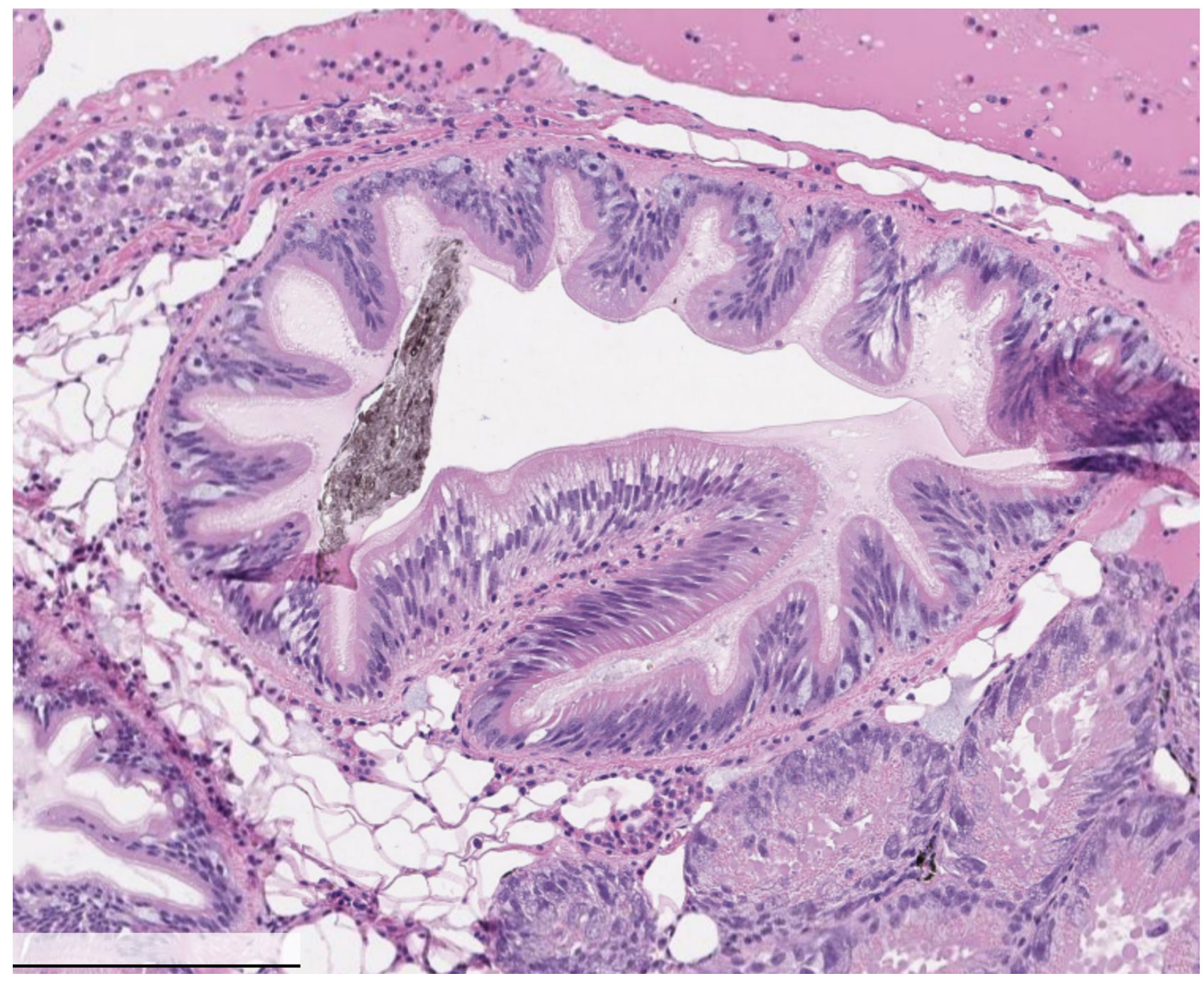

Fig. 16. Microscopic view of Pleurogonius malaclemys in tissues of T. obsoleta (LBIF cyst). Scale bar $250 \mu \mathrm{m}$ 


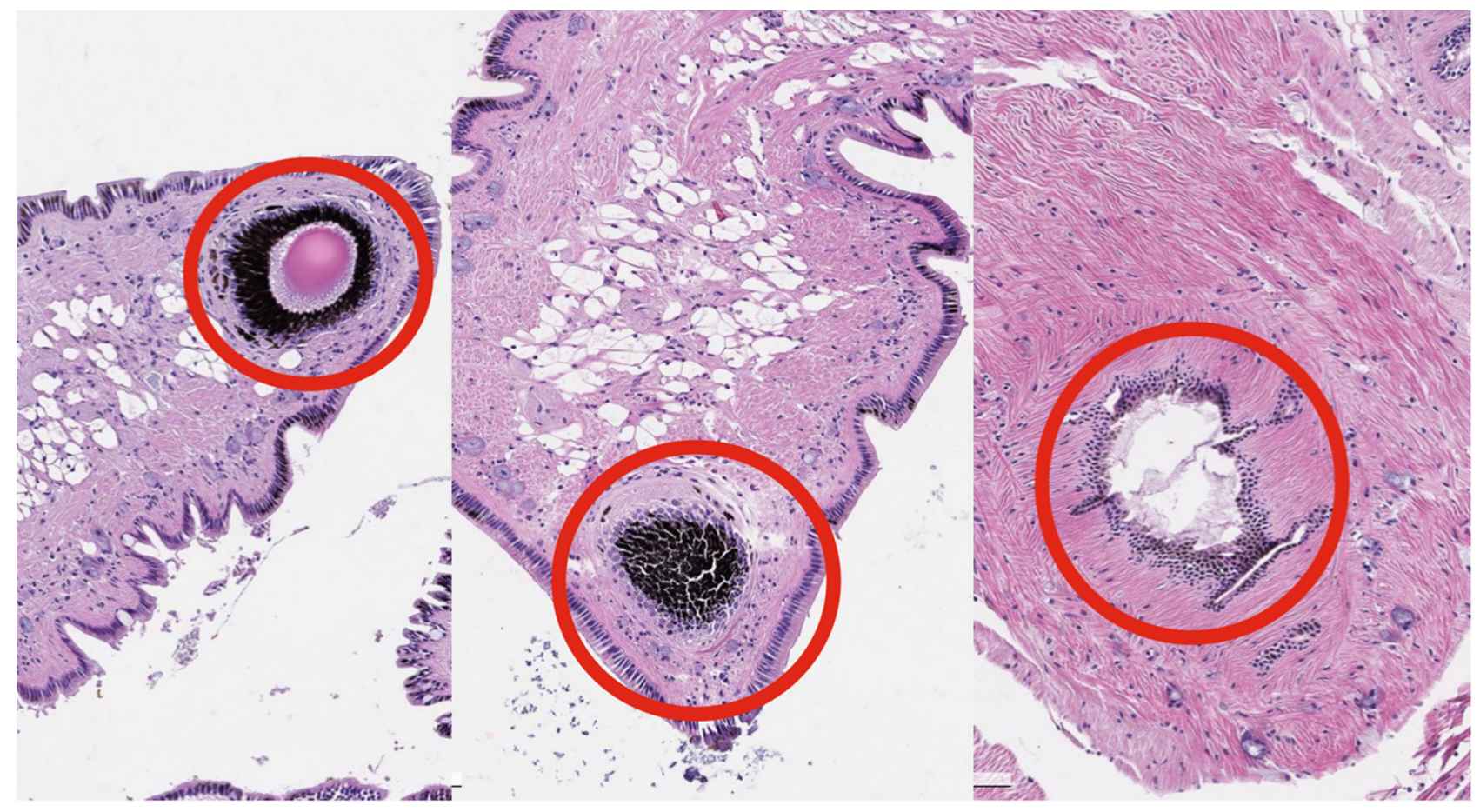

Fig. 17. Microscopic views $(250 \mu \mathrm{m})$ of tissue anomalies in T. obsoleta (IBSP cyst)

at IBSP because the weakened condition and vulnerability of the IBSP snails permits a greater rate of attachment to snails rather than other substrata included in the terrapin diet.

The cyst-free shells at IBSP were found to have significantly higher strontium concentrations than those at LBIF; increased strontium concentrations may be indicative of industrial waste and ash disposal (ATSDR 2004). Besides, strontium, with its chemical properties similar to those of $\mathrm{Ca}$, is known to replace calcium in the structure of aragonite $\left(\mathrm{CaCO}_{3}\right)$ in calcium-deficient conditions (RAGLAND et al. 1969). Metals found only in IBSP shells (arsenic, tantalum, tungsten, and gold) are rarely found in nature, and can be introduced through man-made materials, such as electrical capacitors, light bulbs, and wood preservatives. The snails are vulnerable to contaminants present in the Barnegat Bay, some of which (when available at shell formation) become abnormal components in the shells of T. obsoleta. The calcium concentration in the LBIF shells was consistently higher than that in IBSP shells. Calcium is influential in snail induced defences; molluscs in calcium-poor habitats are not able to efficiently optimise protection against predators and are therefore more vulnerable (RUNDLE et al. 2003). Calcium was found to have a positive relationship with shell weight and thickness (BERG 1941): in calcium-poorer conditions shells become lighter and thinner, which was confirmed in this study. The lower calcium concentrations in IBSP shells further corroborate the statistical significance of differences in the robustness between the snails from the two areas.
The histological analysis revealed P. malaclemys in the tissue of snails with external cysts (Fig. 16), demonstrating the parasite's ability to compromise the health of the snail, not only externally, but also internally as an endoparasite. Tissue deterioration was manifest as holes (white spots on the slides) in the tissue of T. obsoleta with cysts; evincing the parasite's detrimental effects on its host. Tissue abnormalities (some even resembling tumours, such as those in Fig. 17) in mud snails from IBSP could occur as a result of compromised environmental health (OSMAN et al. 2015). Histological abnormalities could also be a result of harmful algal blooms, which are not uncommon in the Barnegat Bay, and have been found to produce tumours and other adverse effects in marine organisms (ROBERTS 2012, REN 2013). The histology of these mud snails is not well studied, and definite conclusions as to the nature of these anomalies cannot be confidently drawn.

Snails often die during the winter months due to food deficit and near-freezing temperatures (MOFFITT \& JAMES 2011). During the winter months of this study, the mud snail populations in both areas suffered a decline. Although the populations were not large, sufficient sample sizes were still found at LBIF. It was extremely difficult to find snails at IBSP, and two IBSP sampling visits had to be repeated due to a lack of any live snails (only shells were found). This significant depletion in the IBSP population may suggest a deteriorating condition of the snails.

It can be concluded that the size and condition of $T$. obsoleta are influenced by a combination of the differences in habitat quality and the prevalence of 
P. malaclemys, as these parameters were significantly different between the two areas. The snails from the area with a poorer sediment and water quality (IBSP) were in a worse physical condition (lighter, with thinner and shorter shells, and a higher prevalence of the parasite), which resulted in their greater vulnerability to both the parasite and the predator. In non-optimum conditions, the parasite can take advantage of the weakened condition of its host. The results provide a unique model of the effects of environmental quality on host-parasite interactions and host health that can be extrapolated to other organisms.

\section{REFERENCES}

AltMAN I. 2010. Trematode parasites of the mudsnail Ilyanassa obsoleta: an analysis of parasite communities at different scales. PhD Thesis, Dissertations 579, University of New Hampshire, Durham. Available online at https://scholars.unh.edu/dissertation/579 (accessed 10 July 2020).

ATSDR (Agency for Toxic Substances and Disease Registry) 2004. Toxicological profile for strontium. Atlanta, GA: U.S. Department of Health and Human Services, Public Health Service. Available online at https://www.atsdr. cdc.gov/toxprofiles/tp159.pdf (accessed 20 February 2020).

Bejda A. J., Phelan B. A., Studholme A. L. 1992. The effect of dissolved oxygen on the growth of young-ofthe-year winter flounder, Pseudopleuronectes americanus. Environmental Biology of Fishes 34: 321. https://doi. org/10.1007/BF00004780

BERG L. R. 1941. The effect of varying levels of calcium intake on the calcium balance, shell thickness, and blood calcium level of White Leghorn pullets. Thesis, Kansas State College of Agriculture and Applied Science. Available online at https://krex.k-state.edu/dspace/ bitstream/handle/2097/24241/LD2668T41941B41. pdf? sequence $=1$ (accessed 10 July 2020).

Bighiu M. A., Watermann B., Guo X., Almroth B. C., ERIKSSON-WIKLUND A. K. 2017. Mortality and histopathological effects in harbour-transplanted snails with different exposure histories. Aquatic Toxicology 190: 11-20. https://doi.org/10.1016/j.aquatox.2017.06.018

BURKE R. L. 2016. Eastern mud snails with parasitic cysts. https://www.flickr.com/photos/107963674@ N07/24499160364 (accessed 10 July 2020)

CHODKOWski N., Williams J. D., BuRKE R. L. 2016. Field surveys and experimental transmission of Pleurogonius malaclemys (Digenea: Pronocephalidae), an intestinal parasite of the Diamondback Terrapin Malaclemys terrapin. Journal of Parasitology 102: 410-418. https://doi. org/10.1645/14-624

COHEN A. N. 2011. The exotics guide: non-native marine species of the North American Pacific Coast. Center for Research on Aquatic Bioinvasions, Richmond, CA, and San Francisco Estuary Institute, Oakland CA. Available

\section{ACKNOWLEDGEMENTS}

I would like to thank Dr. JOHN WNEK, JASON KELSEY, and three anonymous referees for their reviews of my research and this manuscript. I would also like to thank my family for their support, patience, and aid in data collection. In addition, I would like to thank the friends who assisted me in conducting environmental quality tests in the field.

online at http://www.exoticsguide.org (accessed 29 March 2019).

CURTIS L. A. 1997. Ilyanassa obsoleta (Gastropoda) as a host for trematodes in Delaware Estuaries. Journal of Parasitology 83: 793-803. https://doi. org/10.2307/3284270

CURTIS L. A. 2009a. The gastropod Ilyanassa obsoleta as a resource: utilization by larval trematodes in a low-prevalence system. Journal of Parasitology 95: 799-807. https://doi.org/10.1645/GE-1545.1

CURTIS L. A. 2009b. Growth, trematode parasitism, and longevity of a long-lived marine gastropod (Ilyanassa obsoleta). Journal of the Marine Biological Association of the United Kingdom 75: 913-925. https://doi. org/10.1017/S0025315400038248

GUSTAFSON K. D., BOLEK M. G. 2015. Effects of trematode parasitism on the shell morphology of snails from flow and nonflow environments. Journal of Morphology 277: 316-325. https://doi.org/10.1002/jmor.20497

HUNTER W. S. 1967. Notes on the life history of Pleurogonius malaclemys Hunter, 1961 (Trematoda: Pronocephalidae) from Beaufort, North Carolina, with a description of the cercaria. Proceedings of the Helminthological Society of Washington 34: 33-40. Available online at http://bionames.org/bionames-archive/issn/0018 0130/34/33.pdf (accessed 29 March 2019).

JOHNSON D. S., SHORT M. I. 2013. Chronic nutrient enrichment increases the density and biomass of the mudsnail, Nassarius obsoletus. Estuaries and Coasts 36: 28-35. https://doi.org/10.1007/s12237-012-9555-2

LAFFERTY K. D. 2009. The ecology of climate change and infectious diseases. Ecology 90: 888-900. https://doi. org/10.1890/08-0079.1

MierzWA D. 2008. Chemical composition and structure of the shell of Cepaea vindobonensis (Férussac, 1821) (Gastropoda: Pulmonata: Helicidae) from localities of different substrata. Folia Malacologica 19: 97-101. https://doi.org/10.2478/v10125-011-0014-7

MofFitT C. M., JAmES C. A. 2011. Dynamics of Potamopyrgus antipodarum infestations and seasonal water temperatures in a heavily used recreational watershed in inter- 
mountain North America. Aquatic Invasions 7: 193202. https://doi.org/10.3391/ai.2012.7.2.005

OSMAN W., El-SAMAD L. M., MOKHAMER El-H., EL-TOUHAMY A., SHONOUDA M. 2015. Ecological, morphological, and histological studies on Blaps polycresta (Coleoptera: Tenebrionidae) as biomonitors of cadmium soil pollution. Environmental Science and Pollution Research 22: 14104-14115. https://doi.org/10.1007/ s11356-015-4606-4

Ragland P. C., Plikey O. H., BlackWelder B. W. 1969. Comparison of the Sr/Ca ratio of fossil and recent mollusc shells. Nature 224: 1223-1224. https://doi. org $/ 10.1038 / 2241223 \mathrm{a} 0$

REN L. 2013. Baseline characterization of phytoplankton and harmful algal blooms in Barnegat Bay-Little Egg Harbor, New Jersey (Year One). Report prepared for NJDEP-Science and Research and New Jersey Sea Grant. Available online at https://nj.gov/dep/dsr/barnegat/ final-reports/phytoplankton-year1.pdf (accessed 20 February 2020).

ROBERTS C. 2012. The ocean of life: the fate of man and the sea. Penguin Books, New York.

Rundle S. D., Spicer J. I., Coleman R. A., Vosper J., SOANE J. 2003. Environmental calcium modifies in- duced defences in snails. Proceedings of the Royal Society B 271: 67-70. https://doi.org/10.1098/ rsbl.2003.0106

SONG Y., ZHOU Q., SONG X., ZHANG W., Sun T. 2004. [Accumulation of pollutants in sediments and their eco-toxicity in the wastewater irrigation channel of western Shenyang] (in Chinese). Journal of Applied Ecology 15: 1926-1930.

Sures B., NacheV M., Stelbach C., Marcogliese D. J. 2017. Parasite responses to pollution: what we know and where we go in 'Environmental Parasitology'. Parasites \& Vectors 10: 65. https://doi.org/10.1186/ s13071-017-2001-3

TuCKer A. D., Yeomans S. R., GibBons J. W. 1997. Shell strength of mud snails (Ilyanassa obsoleta) may deter foraging by Diamondback Terrapins (Malaclemys terrapin). The American Midland Naturalist 138: 224-229. https://doi.org/10.2307/2426670

Received: March 9th, 2020

Revised: July 11th/22nd, 2020

Accepted: August 8th, 2020

Published on-line: September 2nd, 2020 